\title{
Öğretmen Adaylarına Yönelik Sınıf Yönetimi Algısı Ölç̧eği'nin Geliştirilmesi: Geçerlik ve Güvenirlik Çalışması
}

\author{
Arş. Gör. Gözde Özenç Ira \\ Hacettepe Üniversitesi-Türkiye \\ gozdeozenc@gmail.com
}

\author{
Doç. Dr. Nejat ira \\ Çanakkale Onsekiz Mart Üniversitesi-Türkiye \\ nejat.ira@gmail.com
}

\begin{abstract}
Özet:
Etkili bir sınıf yönetiminin gerçekleşmesinde geleceğin öğretmenleri olan öğretmen adaylarının sınıf yönetim algılarının belirlenmesi önemlidir. Bu çalışmada, sınıf yönetimini yapılandırmacı bakış açısıyla ele alan ve farklı branşlardaki ögrretmen adaylarının yapılandırmacı bir sınıf yönetimi algısına ne kadar sahip olduklarını belirlemeye yönelik, sınıf yönetimini hem öğretimsel hem de davranışsal yönetimi boyutlarda temel alan bir sınıf yönetim algısı ölçeği geliştirilmesi hedeflenmiştir. Ancak araştırmacının sınırı erişimi nedeniyle, az örnekleme ulaşılması ile ancak açımlayıcı faktör analizi ile geçerlik ve güvenirlik analizleri yapılabilmiştir. Bu nedenle bu çalışma, bir ön çalışma olarak belirtilebilir. Ölçek geliştirilirken, Martin ve Sass (2010) çalışması, sınıf yönetimine ilişkin algılarin belirlenmesi için teorik çerçevede temel alınmıştır. Çalışmaya 2017-2018 akademik yılında, Çanakkale Onsekiz Mart Üniversitesi'nde Psikolojik Danışmanlık ve Rehberlik, Almanca Öğretmenliği, Japonca Öğretmenliği ve Beden Eğitimi Öğretmenliği bölümlerinde ögrenim gören toplam 112 ögretmen adayı katılmıştır. Ölçeğin Cronbach's alfa güvenirlik katsayısı .973 olarak bulunmuştur. Ölçek 50 maddeden oluşmaktadır. Tek boyuttan oluşan, 5'li Likert tipindeki Öğretmen Adaylarında Sınıf Yönetimi Algısı ölçeğinin geçerlik ve güvenirliğinin yüksek olması, farklı branşlarda öğrenim gören öğretmen adaylarında geliştirilerek kullanılabilir olduğunu göstermektedir. Bu ölçekteki maddeler farklı sayıda ve farklı örneklemlerle tekrar test edilebilir.
\end{abstract}

Anahtar sözcükler: Sınıf yönetimi, ögretmen adayları, ölçek geliştirme

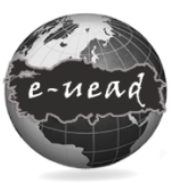

E-Uluslararası Eğitim Araştırmaları Dergisi, Cilt: 9, Sayt: 3, 2018, ss.104-118

DOI: 10.19160/ijer.488221

Gönderim : 08.10.2018 Kabul : 27.11 .2018

\section{Önerilen Atıf}

Özenç İra, G. \&. İra, N. (2018). Öğretmen Adaylarına Yönelik Sınıf Yönetimi Algısı Ölçeği'nin Geliştirilmesi: Geçerlik ve Güvenirlik Çalışması, E-Uluslararası Eğitim Araştırmaları Dergisi, Cilt: 9, Sayı: 3, 2018, ss. 104-118, DOI: 10.19160/ijer.488221 


\section{Giriş}

Sınıf yönetimi, uygun yaklaşım ve yöntemlerden hareketle örgütleme, uygulama ve değerlendirme aracılığıyla sınıf içinde sistematik biçimde etkinliklerin düzenlenmesi olarak ifade edilebilir (Ağaoğlu, 2004). Sınıf, okulun bir alt sistemi olarak eğitim ve öğretim hizmetlerinin üretildiği yerdir. Sınıflarda insan ve madde kaynakları aracılığı ile eğitim programı doğrultusunda öğrenciler yetiştirilmektedir (Toprakçı, 2012). Sınıf yönetimi içerisinde öğretmenin yerine getirdiği işler; öğrenciler ile destekleyici ilişkiler geliştirmek, öğrencilerin öğrenmesini arttıracak biçimde eğitimi düzenlemek, öğrencilerin akademik görevlere katılımını teşvik eden grup çalışmalarını kullanmak, öğrencilerin sosyal ve öz düzenlemelerinin geliştirilmesini teşvik etmek, davranış problemleri olan öğrencilere yardımcı olmak için uygun müdahaleler kullanmak olarak belirtilebilir (Kalin, Peklaj, Pecjak, Levpušcek ve Zuljan, 2017). Sınıf yönetimi, sınıf yaşamının orkestra gibi tüm boyutları ile ele alınıp ahenkli bir şekilde yönetilmesidir (Başar, 1999). Farklı kademelerde çalışan öğretmenlerle gerçekleştirilen çalışmalarda sınıf yönetimine yön veren unsurlar; sınıfın fiziksel koşulları, sınıfta davranış normları oluşturmaya yarayan kuralları oluşturma ve öğrencilerde istenen veya istenmeyen davranışlara ilişkin davranış uygulamaları ile veli, öğretmen ve okul etkileşimine dayalı etkinlikler temelinde bahsedilebilir (Akar, Tantekin Erden, Tor ve Şahin, 2010).

Günümüzde değişen ve gelişen eğitimin rolleri öğretmenin sınıftaki rolü ve sınıf yönetim algısını etkilemektedir (Ercoșkun ve Ada, 2013). Öğretmenin, sınıf içerisinde öğrencilerin özelliklerine uygun etkili bir öğretme öğrenme sürecini gerçekleştirebilmesi için uygun öğretme yolları ile öğrenme-öğretme yöntem ve tekniklerini seçmesi gereklidir (Toprakçıı, 2008). Yapılandırmacı bakış açısıyla, öğrenen öğrenme süreçlerinde aktif olarak ele alınmaktadır. Bu bakış açısılla bireyler, çevre ile etkileşim içinde hareket ederler. Bu bakımdan öğretmenler, öğretmenöğrenci ilişkisinde destekleyici olarak öğrenciler için iyi bir rol modeli olabilmelidir. Stronge, Ward ve Grant (2011), öğretmenlerin sınıf yönetim biçimlerinin, öğrencilerle kurdukları ilişkilerinde belirleyici bir unsur olduğunu ortaya koymaktadır. Öğrenciler kendileri ile ilgilenen bir öğretmeni dinlemek ister, dolayısıyla iyi bir öğrenci-öğretmen etkileşimi, iyi bir sınıf yönetimi için de önemli görülmektedir (Postholm, 2013). Yapılandırmacı yaklaşımın öğretmenlere sınıf yönetimlerinde getirdiği sorumluluklar sadece öğretmen-öğrenci etkileşimi ile değil, öğretmenlerin "düzeni oluşturma", "beş duyuya hitap eden araç-gereç hazırlama", "istenmeyen öğrenci davranışlarına karşı öğretmen davranışı" boyutlarına ilişkin durumlar ile de ilişkilidir (Çandar ve Şahin, 2013, s.113-117).

Etkili sınıf yönetimi, öğretmenlerin mutlaka sahip olması gereken beceriler olarak düşünülmektedir. Nitekim olumlu, öğrenmeyi teşvik edici bir sınıf atmosferi olmadan, öğrencilerin okula bağlı olmasını ve akademik başarı sağlamasını beklemek gerçekçi değildir (Kalin vd., 2017). Yapılan çalışmalar da (Gage, Scott, Hirn ve MacSuga-Gage, 2018; Stronge, Ward ve Grant, 2011), öğretmenlerin sınıf yönetimlerinin iyi olduğu sürece, öğrencilerin öğrenmeleri üzerinde olumlu yönde etkisi olduğunu kanıtlamaktadır. Öğretmenler öğrenciyi temel alan yeni bakış doğrultusunda gelişen rollerini yerine getirebilmesi için sınıf yönetimini etkin ve bilinçli kullanması gerekmektedir (Demirtaș, 2005). Buna rağmen etkili bir sınıf yönetimi oluşturmada öğretmenler sınıf içerisinde bazı problemlerle başa çıkmak zorunda kalabilmektedir. Akın, Yıldırım ve Goodwin (2016, s.786), sınıf öğretmenlerinin sınıf yönetimine ilişkin algılarını ortaya çıkaran fenomenolojik araştırmaları sonucunda, öğretmenlerin sınıf yönetimlerinde yaşadıkları problemlerin "fiziksel çevre", "planlama", "zaman yönetimi", "ilişkilerin yönetimi", "davranış yönetimi" ile ilişkili olduğunu bulmuştur. Yapılandırmacı yaklaşımın sınıf yönetiminde öngörülen katkısı arzu edilir olmakla birlikte, Türkiye'de sınıf yönetiminde öğretmenin otoriter ve geleneksel bir yaklaşım benimsediğini ortaya koyan araştırmalar (Özenç İra ve Çelebi Öncü, 2017; Akar, Tantekin Erden, Tor ve Şahin, 2010) mevcuttur. İlkokul öğretmenlerinin sınıf yönetiminin davranış boyutunu içeren, öğretmenöğrenci etkileşimini kapsayan müdahale yaklaşımlarında orta düzeyde kontrol yaklaşımı benimsediğini ortaya çıkaran araştırma sonuçları (Yılmaz ve Şahin, 2016, Şahin, 2015) ise, 
öğretmenlerin davranış yönetimi uygulamaları bakımından olumlu bir gelişme olarak değerlendirilebilir. İstenmeyen öğrenci davranışlarını kınamak veya cezalandırmak yerine, uygun davranışların güçlendirilmesi yönündeki müdahale yaklaşımları, sınıf içerisinde beklenmedik durumlara karşı olumlu sonuçlar ortaya koymaktadır (Chow ve Gilmour, 2015).

Geçmişten günümüze sınıf yönetimine teorik anlamda atfedilen içeriğin ve boyutların genişlediği belirtilebilir. Sınıf yönetimi ile ele alınan konular davranış kontrolü veya disiplini içeren yapısından gelişerek, öğretimsel etkinlikleri ve planlamaları da içermesi yönüyle daha geniş bir çerçeveye kavuştuğu söylenebilir. Literatür incelendiğinde; Martin ve Baldwin (1993) tarafından sınıf yönetimi kişilik, disiplin ile öğretim boyutlarıyla ele alındığı görülmektedir. Daha sonra sınıf yönetimi Martin, Yin ve Baldwin $(1997,1998)$ ile Martin, Yin ve Mayall (2006) tarafından öğretimsel yönetim, insan yönetimi ile davranışsal yönetim olarak belirlenmiştir. Savran ve Çakıroğlu (2003) ise, davranışsal yönetimi insan yönetiminin içerisine alarak boyutları, öğretimsel yönetim ve insan yönetimi olarak belirtmiştir. Sınıf yönetiminin teorik alt yapısında öğretimsel yönetim; fiziksel çevre, sınıf rutinleri, öğretimsel planlamalar ve uygulamalar ile açıklanabilir. Davranışsal yönetim ise benimsenen disiplin yaklaşımları (Martin ve Baldwin, 1993), öğrenciye bildirim ve yönergelerin verilmesi, kuralların oluşturulması, ödül ve ceza kullanımı (Martin, Yin ve Baldwin, 1997; Martin, Yin ve Mayall, 2006) kapsamında ifade edilebilir. Bu çalışmalarda davranışsal yönetim boyutlarının, ödül ve cezanın kullanımı ile daha çok geleneksel bir disiplin anlayışına işaret ettiği belirtilebilir.

Daha yakın zamanda ise Martin ve Sass (2010) tarafından sınıf yönetimi, davranışsal ve öğretimsel yönetimi içeren iki boyutlu bir yapıda gösterilmiştir. Sass, Lopes, Oliveira ve Martin (2016) Portekizli öğrenciler ile gerçekleştirdikleri çalışmada, sınıf yönetimi boyutlarını yine davranışsal ve öğretimsel olarak ortaya koymuştur. Bu çalışmalarda, davranışsal yönetim boyutunda yer alan öğretmen-öğrenci etkileşimi, Glickman ve Tamashiro (1980) tarafından çerçevesi çizilen ve öğretmenlerin disiplin algılarına yönelik kontrol yaklaşımlarını ifade eden teoriyi temele almıştır (Sass, Lopes, Oliveira ve Martin, 2016, s.280). Bu yaklaşıma göre öğretmenler, öğrencileri ile etkileşimlerinde, müdahaleci, müdahaleci olmayan ve etkileşimci bir yaklaşım izlemektedirler (Glickman ve Tamashiro, 1980, s.460). Şahin-Sak, Tantekin-Erden ve Pollard-Durodola $(2018$, s.102) okul öncesi öğretmenleri ile yaptıkları çalışmada, Martin ve Sass'ın (2010) teorik yapısını temel alarak sınıf yönetim boyutlarını; "fiziksel çevreyi organize etme", "etkinlikleri programlama ve planlama", "sınıfta etkileşim ve iletişim oluşturma", "çocukların davranışının yönetilmesi" olarak belirlemiştir.

Türkiye'de sınıf yönetimi ile ilgili ölçek geliştirme çalışmaları incelendiğinde; Şahin ve Altunay (2011) sınıf öğretmenlerinin sınıf yönetim davranışlarını belirleyen bir ölçek geliştirmiştir. Ayrıca, sınıf içi istenmeyen davranışlarına ilişkin öğretmenlerin tutumlarını (Tanhan ve Şentürk, 2011), öğretmen adaylarının sınıf yönetimi yeterliklerini (Elçiçek, Kinay ve Oral, 2015), sınıf öğretmenlerinin sınıf yönetimine ilişkin genel yeterliklerini (Gökçe, 2015), fen bilimleri öğretmenlerine yönelik sınıf yönetimini (Temli-Durmuș, 2016), lisede öğrenim gören öğrencilerin sınıf yönetimi becerilerini (Özcan ve Gülözer, 2017) belirlemeye yönelik ölçek geliştirme çalışmalarının yapıldığı görülmektedir. Sınıf yönetimi uyarlama çalışmalarının ise, Martin, Yin ve Baldwin (1998) temel alınarak, Savran ve Çakıroğlu'nun (2004) fen bilimleri öğretmen adaylarında uyarladığı sınıf yönetimi ölçek çalışması; Akın, Erguvan, Sarıçam, Yalnız, Güler ve Özdemir (2013) tarafından Martin ve Sass (2010) çalışmasının farklı branşlarda çalışan öğretmenlerde uyarlama çalışması, Aktan ve Sezer'in (2018), Bosworth (1997) tarafından geliştirilen Sınıf Yönetimi Stilleri Ölçeği'ni farklı branşlarda görev yapan öğretmenlerde uyarlama çalışması mevcuttur. Bu anlamda çeşitli branşlardaki öğretmenlerin sınıf yönetim yeterliklerini, becerilerini, stillerini ortaya koyacak ölçek geliştirme ve uyarlama çalışmalarının yapıldığı görülmektedir. Ancak sınıf yönetimine yönelik gelişen anlayış ve eğitime yönelik inançlar, bu kavramın güncel bir biçimde tekrar yapılandırılması gerektiğini düşündürmektedir. Bu nedenle, bu çalışmaya sınıf yönetiminin yapılandırmacı paradigma ile ilişkisi düşünülerek ve okul, aile gibi paydaşların katılımı göz önüne alınarak kuramsal olarak test edilmesi intiyacının belirlenerek başlandığı belirtilebilir. Bu tür bir ölçek 
geliştirme çalışmasının, benzer sınıf yönetimi algısı çalışmalarını yapılandırmak için bir ön çalışma olarak katkı sağlayacağı belirtilebilir.

Günümüze kadar sınıf yönetiminin disiplin ile eş kullanımı söz konusudur (Martin ve Sass, 2010). Ancak günümüzde sınıf yönetiminde istenmeyen davranışlar karşısında ceza kullanımını da ifade eden geleneksel disiplin anlayışı yerine, önleyici müdahale yaklaşımları ve öğrenci-öğretmen etkileşimini temel alan bir yaklaşım benimsenmektedir. Disiplin bu bakımdan davranış yönetiminin kapsamında düşünülmektedir. Ayrıca öğretimsel uygulamalar ile davranış yönetimi sınıf yönetiminde beraber ele alınmaktadır. Bu anlayışın sınıf yönetimine ait ölçek çalışmalarına da yansıtılmasının önemli olduğu belirtilebilir. Nitekim sınıf yönetime ilişkin algıların yapılandırmacı bakış açısıyla revize edildiği, davranışsal ve öğretimsel boyutlarda farkıı branşlarda öğrenim gören öğretmen adaylarında yapı özelliklerinin incelendiği bir ölçek geliştirme çalışmasına rastlanılmamıştır. Sınıf yönetiminde gelişen bu anlayış ile ölçek çalışmaları yapılması intiyacının olduğu söylenebilir. Bu nedenle bu çalışmada, Martin ve Sass'ın (2010) sınıf yönetimi boyutlarını davranışsal ve öğretimsel yönetim olarak ele aldığı çalışması, teorik çerçevede temele alınmıştır. Böylelikle öğretmenlerin sınıf içerisinde öğrenme hedeflerini gerçekleştirirken, aynı zamanda davranış yönetimini de gerçekleştirdikleri düşünülmektedir. Örneğin bir öğretmen, öğrenci merkezli öğretim yöntemleri olan tartışma ve aktif sorgulama gibi yöntemleri uygularken, sınıfında yüksek seviyede bir gürültü oluşabilir ve bunun sonucunda öğretmen davranış yönetimi sıkıntıları ile başa çıkmak zorunda kalabilmektedir (Martin ve Sass, 2010). Aynı zamanda öğretmen öğrenci ile etkileşiminde müdahaleci, müdahaleci olmayan ve etkileşimci bir yaklaşıma sahip olabilir. Yapılandırmacı yaklaşıma göre de, öğretmenden beklenen, öğrencilerin merkeze alındığı ve kendi sorunlarının çözümü için desteklendiği etkileşimci yaklaşımdır. Farklı branşlardaki öğretmen adaylarının sınıf yönetim algılarına ilişkin giriş niteliğinde olan bu ölçek geliştirme çalışmasının, hem sınıf yönetim boyutlarının yapısını ortaya koyması hem de güncel olması nedeniyle ilgili literatüre katkı sağlayacağı düşünülebilir.

\subsection{Araştırmanın Amacı}

Bu çalışmada, sınıf yönetimini yapılandırmacı bakış açısıyla ele alan ve farklı branşlardaki öğretmen adaylarının yapılandırmacı bir sınıf yönetimi algısına ne kadar sahip olduklarını belirlemeye yönelik, sınıf yönetimini hem öğretimsel hem de davranışsal yönetimi boyutlarında temel alan bir sınıf yönetim algısı ölçeği geliştirilmesi hedeflenmiştir. Nihai ölçekteki maddeler $(6,15,16,17,18,19,20,21,22,23,24,25,26,27,28,32,33,34,35,37,38,41,44,45,47,48,49$ ve 50 .); davranış yönetimi ilgili kuramdan yararlanılarak ve veli ile okul işbirliği ve yapılandırmacılık paradigması ile yapılandırılarak belirlenmiştir. Diğer maddelerin ise, öğretimsel yönetim ile ilişkili olarak oluşturulmak istendiği belirtilebilir. Bu çalışma, farklı branşlardaki öğretmen adaylarııın sınıf yönetim algıları için çalışılması, yapılandırmacı yaklaşımı temele alması ve sınıf yönetimini davranışsal ve öğretimsel yönetim boyutları ile ele alması ile yeni bir çalışma olarak değerlendirilebilmesi nedeniyle, yapının keşfedilmesi ve ortaya çıkarılması için giriş niteliğinde bir ölçek geliştirme çalışması olarak belirtilebilir. Bu nedenle bu çalışmanın, belirlenen maddeleri temel alan, daha büyük örneklemlerle çalışılan bir ölçek geliştirme çalışmasına temel olması düşünülmektedir. Bu çalışmada maddeler oluşturulurken, Martin ve Sass'ın (2010) teorik çerçevesi temel alınmıştır. Buna göre, öğretmenlerin öğretimsel ve davranışsal yönetimleri birbiri ile ilişkilidir. Öğretmenlerin sınıf içi uygulamaları, sınıf yönetimine olan algıları ile ilgilidir. Davranışsal yönetim; öğretmen-öğrenci ilişkisinde etkileşimci davranılması, öğrenciye bildirim verilmesi, öğrenciye değer verilmesi, kurallar oluşturma ve istenmeyen öğrenci davranışlarını önlemede önleyici müdahale yaklaşımlarının benimsenmesi, öğrencinin sosyal bağlamda temele alması yönüyle okul-aile ve veli işbirliğine önem verilmesi kapsamında belirtilebilir. Öğretimsel yönetim; öğrenciyi temele alan öğretim yöntemlerinin belirlenmesi, sınıfın fiziksel ortamını planlanması, zamanın etkili yönetilmesi, öğretim hedeflerini gerçekleştirmek için yapılan diğer planlamalar ve araç-gereç hazırlanması olarak belirtilebilir. Bu bakımdan öğretmen adaylarının sınıf yönetimine 
olan algıları olumlu oldukça, bahsedilen boyutlardaki uygulamalara yönelik algıları da pozitif yönde olabilecektir. Öğretmen adaylarının bir çocuğun nasıl yetiş̧tirilmesi gerektiğini yansıtan sınıf yönetimi algıları, onların sınıf içerisindeki davranışlarının da belirleyicisi olarak düşünülebilir. Öğretmen adaylarının geleceğin öğretmenleri olması yönüyle, sınıf yönetimine ilişkin olumlu algıya sahip olmaları beklenmektedir. Öğretmen adaylarının algılarının istendik yönde olmaması, sınıf yönetimine ilişkin verilen eğitimin planlamasında değişikliklere gidilerek program içeriğinin düzenlenmesine katkı sağlayabilir. Öğretmen adaylarının sınıf yönetimine yönelik algılarının belirlenmesi ve çeşitli değişkenlerce ilişkisinin incelenmesi, öğretmen yetiştirme politikalarının gözden geçirilmesine katkı sağlayacağı düşünülebilir.

\section{YÖNTEM}

Öğretmen adaylarının sınıf yönetimi algılarını ölçmek amacıyla geliştirilen ölçeğin adı, Öğretmen Adaylarında Sınıf Yönetimi Algısı Ölçeği olarak belirlenmiştir. Ölçeğin geliştirilme sürecinde izlenen adımlar aşağıda belirtilmiştir.

\section{1. Çalışma Grubu}

Çalışma grubu, Çanakkale Onsekiz Mart Üniversitesi, 2017-2018 öğretim yılında, eğitim fakültesi ve spor bilimleri fakültesi beden eğitimi bölümünde öğrenim gören öğretmen adaylarından oluşmaktadır. Bu okul, yabancı diller bölümlerinin bulunması ve araştırmacının erişiminin kolay olması yönüyle seçilmiştir. Çalışma grubunda 63'ü kadın (\%56,25), 49'u erkek $(\% 43,75)$ olmak üzere toplam 112 öğretmen adayı yer almaktadır. Faktör analizi için kabul edilebilen minimum örneklem büyüklüğü, Gorsuch (1983)'e göre 100 iken, Tabachnick ve Fidell'e (2007) göre, 150'dir. Cattel (1978) ise, ölçekteki maddelerin 3 veya 6 katı kadar örnekleme ulaşılması gerektiğini belirtmektedir. Bu bakımdan bu çalışmada faktör analizi için önerilen öğretmen adayı sayısı az görünmekle birlikte, erişilebildiği kadar öğretmen adayı çalışmaya dâhil edilebilmiştir. Bu öğretmen adayları basit seçkisiz örnekleme yöntemi ile seçilmiştir. Öğretmen adaylarının 60'ı Psikolojik Danışmanlık ve Rehberlik (\%53,57), 12'si Almanca Öğretmenliği $(\% 10,71), 18$ 'i Japonca Öğretmenliği $(\% 16,07), 22$ 'si Beden Eğitimi Öğretmenliği $(\% 19,65)$ bölümlerinde öğrenim görmektedir. Psikolojik Danışmanlık ve Rehberlik bölümünde öğrenim gören öğretmen adaylarının, örneklemin yarısını oluşturması $(\% 53,57)$, bu çalışmanın örneklem seçimindeki bir sınırlılığı olarak ifade edilebilir. Bu ölçek ortaokul ve ortaöğretim branş öğretmen adaylarına yönelik hazırlanmak istenmesi sebebiyle, bahsedilen branşlar çalışma grubu olarak seçilmiştir.

Ölçek geliştirmek için şu çalışmalar yapılmıştır:

- Madde havuzu oluşturulurken öncelikle sınıf yönetimi ile ilgili makale, kitap ve tezler taranmıştır. İlgili maddeler, Martin ve Sass (2010) çalışması temel alınarak, öğretimsel ve davranışsal sınıf yönetim boyutları çerçevesinde hazırlanmıştır. Maddelerin belirlenmesinde alan uzmanlarının görüşleri, yapılandırmacı yaklaşımın sınıf yönetimine etkisi, öğretmen adaylarının etkili sınıf yönetimine yönelik açık uçlu sorulara verdikleri cevaplarda teoriye uygun olanlarının seçilmesi işlemleri ile süreç başlatılmıştır. Çanakkale Onsekiz Mart Üniversitesi'nde Psikolojik Danışmanlık ve Rehberlik, Almanca Öğretmenliği, Japonca Öğretmenliği ve Beden Eğitimi Öğretmenliği bölümlerinde öğrenim gören 15 öğretmen adayından sınıf yönetiminin kavramsal çerçevesini çizebilmek için 5 açık uçlu soruyu (Sizce sınıf yönetimi nedir? Etkili bir sınıf yönetimi nasıl olmalıdır? lyi bir sınıf yönetimi sağlamaya yönelik öğretmenler nelere dikkat etmelidir? Öğretmen istenmeyen öğrenci davranışları karşısında nasıl davranmalıdır? Etkili bir sınıf yönetimi öğretmen ve öğrenciler için ne gibi avantajlı durumlar sağlayacaktır?) yanıtlamaları istenmiştir. Bu sorular, öğretmen adaylarının etkili sınıf yönetiminin nasıl olması gerektiğine dair algılarını ortaya çıkarmaya ilişkindir. 
- Literatür taraması ve gelen yanıtlar sonucunda araştırmacı tarafından sınıf yönetimi algısı için 51 maddeyi içeren madde havuzu yapılandııımıştır.

- Kapsam geçerliği amacıyla dördü eğitim bilimlerinde uzman olan öğretim üyelerinin görüşü alınmıştır. Değerlendirmeler sonucunda, bazı ifadeler yeniden düzenlenmiş ve yeni ifadeler eklenmiştir. Bu ifadeler, sınıf yönetimindeki kuramsal temele uygun olarak oluşturulmuştur. Sınıf yönetimi algısını ortaya çıkaracağı düşünülen toplamda 57 maddelik ölçek oluşturulmuştur. Maddelerin dil yönünden incelenmesi için iki Türkçe bölümü öğretim üyesine başvurulmuştur. Biri de ölçme ve değerlendirme uzmanı olan bir öğretim üyesinden görüş alınmıştır.

- Katılımcıların, "5=Tamamen katılıyorum", "4=Genellikle katılıyorum", "3=Kararsızım", "2=Katılmıyorum", "1=Asla katılmıyorum" ifadelerini işaretleyerek, 5'li Likert tipi bir ölçek ile algıları belirlenmek istenmiştir.

\subsection{Verilerin Toplanması}

Ölçek, Çanakkale Onsekiz Mart Üniversitesi'nin eğitim fakültesinde 2017-2018 öğretim yılında öğrenim görmekte olan 63'ü kadın ve 49'u erkek olmak üzere toplam 112 öğretmen adayına uygulanmıştır. Katııımcılara araştırmanın amacı hakkında kısa bilgi verilmiş ve uygulama aşamasında nelere dikkat etmeleri gerektiği konusunda Sınıf Yönetimi Algısı Ölçeği'nin giriş kısmına bilgi notu eklenmiştir. Öğrencilerin isimlerini yazmamaları istenmiş, ancak değerlendirmede kullanılacak bazı genel kişisel verileri işaretlemeleri belirtilmiştir. Ölçeğin uygulanması yaklaşık 15-20 dakikalık bir süreyi kapsamaktadır.

\subsection{Verilerin Analizi}

Verilerin analizinde KMO, Barlett testi, aritmetik ortalama, yüzde, faktör analizi ile güvenirlik analizleri kullanıımışıı. Bu çalışmada faktör yapısını belirlemek ve alt ölçekler keşfedilmek istendiği için, "değişkenler arasındaki ilişkilerden hareketle faktör bulmaya yönelik bir işlem" Büyüköztürk (2016, s.133) olan açımlayıcı faktör analizi yapılmıştır. Açımlayıcı faktör analizi, temel bileşenler analizi ile gerçekleştirilmiştir. "Faktör analizi, birbiriyle ilişkili değişkenleri bir araya getirerek az sayıda ilişkisiz ve kavramsal olarak anlamlı yeni alt boyutlar bulmayı amaçlayan çok değişkenli bir istatistiktir. Açımlayıcı faktör analizinde, değişkenler arasındaki ilişkilerden hareketle faktör bulmaya yönelik bir işlem söz konusudur" (Büyüköztürk, 2016, s.134). Verilerin analizinde SPSS 24.0 programı kullanılmıştır.

Açımlayıcı faktör analizinde, faktör özdeğerlerinin 1'in üzerinde olması, madde yüklerinin .30 ve üzerinde faktör yükünün olması, maddelerin yük değerlerinin öteki faktörlerdeki yük değerleri ile.10 ve üzeri fark göstermesi (Büyüköztürk, 2016) ölçütleri dikkate alınmıştır.

\section{BULGULAR}

Aşağıdaki tabloda, Bu çalışmada verinin faktör analizine uygunluğunun saptanması için hesaplanan Kaiser Mayer Olkin (KMO) katsayısı ile verinin faktör analizine yapısal olarak ne kadar iyi uyum gösterdiğini açıklayan Barlett Testi sonuçları verilmektedir.

Tablo 1:

Ögrretmen Adaylarında Sınıf Algısı Ölçeği'nin KMO ve Bartlett Testi Sonuçları

\begin{tabular}{llc}
\hline KMO & & .924 \\
\hline Bartlett Testi & Chi-Square & 7281,388 \\
\hline & df & 1596 \\
\hline & p & .000 \\
\hline
\end{tabular}

Bu çalışmada verinin faktör analizine uygunluğunun saptanması için hesaplanan Kaiser Mayer Olkin (KMO) katsayısının " .924" olduğu görülmektedir. KMO katsayısının 0.80 değerinin üzerinde olması, datanın faktör analizine yapısal olarak iyi uyum gösterdiğini kanıtlamaktadır. 
Barlett Testi sonucu elde edilen Ki-Kare değeri 7281,388; df:1596, p: .000 anlamlı çıkması, verilerin birbiri ile ilişkili olduğunu göstermektedir. Tablo 2'de varyans oranları ve özdeğer sonuçları verilmektedir.

\section{Tablo 2:}

Faktör Analizine Illişkin Özdeğer ve Varyans Sonuçları

\begin{tabular}{llll}
\hline Faktörler & Özdeğer (Eigenvalue) & Açıklanan Varyans & Toplam Varyans \\
\hline 1 & 29,074 & 51,006 & 51,006 \\
\hline
\end{tabular}

Yapılan faktör analizi ile ölçeğin toplam varyansın \% 51,006'sını açıklayan, özdeğeri 1,00'ın üstünde olan bir yapı tek faktör olarak elde edilmiştir. Büyüköztürk (2016, s.135) açıklanan varyans oranı için, "tek faktörlü ölçeklerde açıklanan varyansın \%30 ve daha fazlası olması yeterli görülebilir" olarak belirtmektedir. Maddelerin faktör yükleri ".840" ile ".326" arasındadır. Maddelerden .30'un altında yer alan 7 madde atılmıştır.

Tablo 3:

Madde Havuzundan Çıkartılan Maddelerin Faktör Yük ve Madde Toplam Korelasyonları

\begin{tabular}{lll}
\hline Madde Havuzundan Çıkartılan Maddeler & Faktör Yükü & $\begin{array}{c}\text { Madde-Toplam } \\
\text { Korelasyonları }\end{array}$ \\
\hline Madde 9- Etkinliklerin süreleri öğretmen tarafından önceden planlanmalıdır. & .010 & .164 \\
\hline Madde 10- Öğrencilerin derse ilgili olması çin öğretmen çaba harcamamalıdır. & .050 & .278 \\
\hline $\begin{array}{l}\text { Madde 30- Öğretmenler disiplini sağlamada tamamen kendi tecrübelerinden } \\
\text { yararlanmalıdır. }\end{array}$ & .003 & .120 \\
\hline $\begin{array}{l}\text { Madde 33- Öğretmenler istenmeyen davranışlarda bulunan öğrencileri anında } \\
\text { cezalandırmalıdır. }\end{array}$ & .013 & .178 \\
\hline $\begin{array}{l}\text { Madde 41- Öğretmen planladığı Öğretimsel uygulamalarını çeşitlendirmemelidir. } \\
\text { Madde 44- Öğretmen dersin akışını bozmamak için teknolojik araçları } \\
\text { kullanmamalıdır. }\end{array}$ & .042 & .199 \\
\hline $\begin{array}{l}\text { Madde 54- Öğretmen kendi otoriter gücünü, öğrenciler üzerinde baskı } \\
\text { oluşturmak için kullanabilmelidir. }\end{array}$ & .012 & .273 \\
\hline
\end{tabular}

Tablo 3'te gösterilen maddelerin olumsuz ifadeleri belirtmesi hedeflenmiştir ancak faktör yükleri ve madde-toplam korelasyonları düşük olması sebebiyle ölçekten çıkartılmıştır. Tablo 4 'te Öğretmen Adaylarında Sınıf Yönetimi Algısı Ölçeği tek faktör yapısına ilişkin faktör yük ve madde toplam korelasyonları verilmektedir.

\section{Tablo 4:}

Öğretmen Adaylarında Sınıf Yönetimi Algısı Ölçeği Faktör Yük ve Madde Toplam Korelasyonları

\begin{tabular}{lll}
\hline Maddeler & Faktör Yükü & \multicolumn{1}{c}{$\begin{array}{c}\text { Madde-Toplam } \\
\text { Korelasyonları }\end{array}$} \\
\hline $\begin{array}{l}\text { Madde 1- Öğretmenler öğrencilerin ilgi ve ihtiyaçlarına göre etkinlikleri } \\
\text { planlamalıdır. }\end{array}$ & .589 & .741 \\
\hline $\begin{array}{l}\text { Madde 2- Öğretmen öğretimsel etkinliklerinde öğretim yöntemlerinden karma } \\
\text { bir şekilde yararlanabilmelidir. }\end{array}$ & .438 & .652 \\
\hline $\begin{array}{l}\text { Madde 3- Öğretmenler etkinliklerde araştırma stratejisine dayalı yöntem ve } \\
\text { teknikleri kullanarak öğrenciyi aktif kılmalıdır. }\end{array}$ & .420 & .612 \\
\hline $\begin{array}{l}\text { Madde 4- Öğretmenin öğretim etkinliklerini dönem başında/derse girmeden } \\
\text { önce planlamalıdır. }\end{array}$ & .385 & .590 \\
\hline $\begin{array}{l}\text { Madde 5- Öğretmen önceden belirlemiş olduğu günlük planlarını büyük ölçüde } \\
\text { uygulayabilmelidir. }\end{array}$ & .380 & .591 \\
\hline $\begin{array}{l}\text { Madde 6- Öğretmenin zamanı planlarken ders akışını engelleyebilecek olasılıkları } \\
\text { göz önünde bulundurmalıdır. }\end{array}$ & .552 & .708 \\
\hline \begin{tabular}{l} 
Madde 7- Etkinliklerin geçişi öğretmen tarafından önceden planlanmalıdır. \\
\hline
\end{tabular} & .471 & .656 \\
\hline
\end{tabular}




\begin{tabular}{|c|c|c|}
\hline Madde 8- Etkinliklerin süreleri öğretmen tarafından önceden planlanmalıdır. & .555 & .730 \\
\hline Madde 9- Öğretmenlerin zaman yönetimi etkili olmalıdır. & .636 & .784 \\
\hline $\begin{array}{l}\text { Madde 10-Öğretmen sınıfında işbirlikli öğretim yöntemlerinin kullanımını } \\
\text { önemsemelidir. }\end{array}$ & .461 & 649 \\
\hline $\begin{array}{l}\text { Madde 11- Öğretmen öğreteceği konu alanına hâkim olmalı ve günceli takip } \\
\text { edebilmelidir. }\end{array}$ & .704 & .821 \\
\hline Madde 12- Öğretmen ders materyallerini önceden hazırlayarak derse gelmelidir. & .497 & .674 \\
\hline Madde 13-Öğretmen öğrencilerin seviyelerine uygun şekilde dersi işlemelidir. & 641 & .777 \\
\hline Madde 14- Öğretmen öğrencilerin geçmiş öğrenmelerini dikkate almalıdır. & .420 & .630 \\
\hline Madde 15- Öğretmen öğrencilerin sorularına dönüt vermelidir. & .791 & .858 \\
\hline $\begin{array}{l}\text { Madde 16- İstenmeyen davranışlar karşısında öğretmen gerekli müdahaleyi } \\
\text { doğru yer ve zamanda yapabilmelidir. }\end{array}$ & .703 & .814 \\
\hline Madde 17- Öğretmen sınıfını demokratik bir şekilde yönetmelidir. & .593 & .750 \\
\hline $\begin{array}{l}\text { Madde 18-Öğretmen çatışma yönetimini bilmelidir/öğrencilerle güç yarışına } \\
\text { girmemelidir. }\end{array}$ & .703 & .822 \\
\hline $\begin{array}{l}\text { Madde 19- Öğretmenler istenmeyen davranışlara kaynaklık eden nedenleri } \\
\text { bulmalıdır. }\end{array}$ & .593 & .746 \\
\hline Madde 20- Öğretmen konuyu anlamayan öğrenciye hoşgörülü davranmalıdır. & .670 & .790 \\
\hline Madde 21- Öğretmen tüm öğrencilere adil davranmalıdır. & .801 & .868 \\
\hline Madde 22- Öğretmen tüm öğrencilere eşit davranmalıdır. & .580 & .729 \\
\hline Madde 23-Öğretmen öğrencilerine güven vermelidir. & .798 & .866 \\
\hline Madde 24- Öğretmen öğrencilere sözel şiddet uygulamamalıdır. & .705 & .820 \\
\hline Madde 25-Öğretmen öğrencilere fiziksel şiddet uygulamamalıdır. & 613 & .768 \\
\hline $\begin{array}{l}\text { Madde 26- Öğretmen eğitim-öğretim yılının başında öğrencilerin katılımıyla } \\
\text { kuralları belirlemelidir. }\end{array}$ & .334 & .565 \\
\hline Madde 27- Öğretmen öğrencileri bir birey olarak saygı göstermelidir. & .840 & .886 \\
\hline $\begin{array}{l}\text { Madde 28- Öğretmenler olası istenmeyen durumlar için önceden önlemler } \\
\text { almalıdır. }\end{array}$ & .467 & .652 \\
\hline $\begin{array}{l}\text { Madde 29-Okul yönetimi, sınıftaki öğretim etkinliklerini destekleyecek kararlar } \\
\text { almalıdır. }\end{array}$ & .479 & .667 \\
\hline $\begin{array}{l}\text { Madde } 30 \text { - Etkili sınıf yönetimi sağlayabilmek için öğretmenler okulun eğitim } \\
\text { politikalarını belirlemede söz sahibi olmalıdır. }\end{array}$ & .336 & .543 \\
\hline $\begin{array}{l}\text { Madde 31- Öğretmenin gerçekleştirmek istediği etkinlikler okul yönetimince } \\
\text { desteklenmelidir. }\end{array}$ & .505 & .716 \\
\hline $\begin{array}{l}\text { Madde 32- Velilerin olumlu desteği öğrencilerin sınıf kurallarını uymasını } \\
\text { kolaylaştııır. }\end{array}$ & .460 & .647 \\
\hline $\begin{array}{l}\text { Madde 33- Öğretmenlerin öğrencilerine daha iyi rehberlik edebilmesi için, veli } \\
\text { toplantılarında birlikte kararlar alınmalıdır. }\end{array}$ & .411 & .613 \\
\hline Madde 34- Veli ile yapılan işbirliği çocuğun tüm yönleriyle gelişimini destekler. & .633 & .775 \\
\hline $\begin{array}{l}\text { Madde 35-Öğretmenler çocuğun okulda kazandığı bilgileri pekiştirebilmesi için } \\
\text { ailelerle işbirliği içerisinde olmalıdır. }\end{array}$ & .664 & .795 \\
\hline $\begin{array}{l}\text { Madde 36- Okul-aile bağını güçlendirmek için öğretmenler ailelerin sınıf } \\
\text { etkinliklerine katılma fırsatı vermelidir. }\end{array}$ & .327 & .556 \\
\hline $\begin{array}{l}\text { Madde 37-Öğretmenler aileleri çocukların eğitimlerine yardım etmeleri } \\
\text { konusunda bilinçlendirmelidir. }\end{array}$ & .715 & .834 \\
\hline $\begin{array}{l}\text { Madde 38-Öğretmenin etkili iletişim becerilerini bilmesi sınıf yönetimi başarısını } \\
\text { arttıır. }\end{array}$ & .594 & .766 \\
\hline $\begin{array}{l}\text { Madde 39- Öğretmenler sınıf yönetimlerinde kendilerini daha yetkin } \\
\text { hissedebilmeleri için teknolojik yeterliklerini arttırmalıdırlar. }\end{array}$ & .474 & .670 \\
\hline $\begin{array}{l}\text { Madde 40- Öğretmenler öğrencilerin derse katılımlarını arttırmak amacıyla } \\
\text { sınıfta teknolojik araçları etkin kullanabilmelidir. }\end{array}$ & .551 & .731 \\
\hline Madde 41- Öğretmen öğrencileri tarafından sevilmelidir. & .326 & .529 \\
\hline Madde 42- Öğretmen gelişmeye açık olmalıdır. & .782 & .874 \\
\hline Madde 43- Öğretmen bilimsel olmalıdır. & .611 & .752 \\
\hline Madde 44- Öğretmen lider özellikleri taşımalıdır. & 601 & .739 \\
\hline Madde 45- Öğretmen kendisini iyi tanımalıdır. & .821 & .873 \\
\hline Madde 46- Öğretmen alanı ile ilgili yeniliklere açık olmalıdır. & .729 & .834 \\
\hline Madde 47- Öğretmen öğrencileriyle empati kurabilmelidir. & .731 & .836 \\
\hline $\begin{array}{l}\text { Madde 48- Öğretmenin öğrencileriyle daha iyi iletişim kurabilmesi için } \\
\text { öğrencilerini sosyo-kültürel özellikleri yönüyle tanıyabilmelidir. }\end{array}$ & .609 & .761 \\
\hline $\begin{array}{l}\text { Madde 49-Öğretmen öğrencilerin derse uyumunu kolaylaştırabilmek için } \\
\text { öğrencilerine yakınlık gösterebilmelidir. }\end{array}$ & .425 & 616 \\
\hline
\end{tabular}


Ölçekte yer alan maddelerin faktör yükleri ".840" ile ".326" arasında değişmektedir. Ölçeğin Cronbach's alfa güvenirlilik katsayısı .973 'dür ve ölçeğin güvenirliğinin yüksek olduğu belirtilebilir.

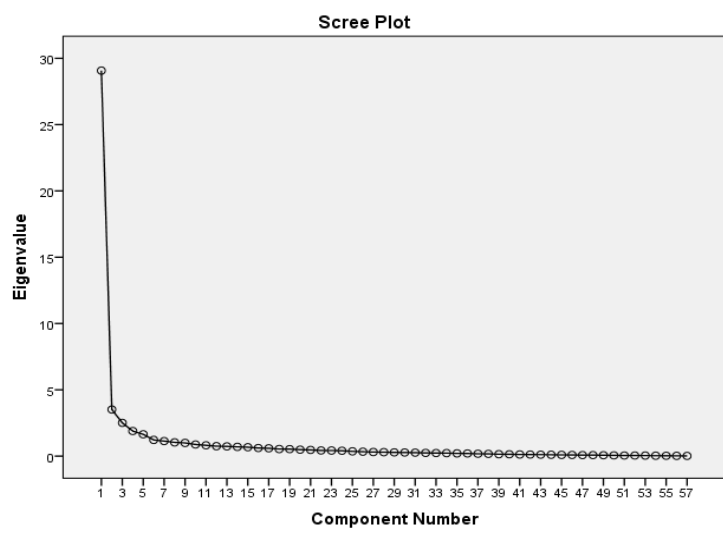

Şekil 1:

Öğretmen Adaylarında Sınıf Yönetimi Algısı Ölçeğinin Yamaç Eğim (scree plot) Grafiği

Yamaç eğim (scree plot) grafiği incelendiğinde, ölçeğin tek faktör yapısına sahip olduğu söylenebilir. Ölçekte yer alan maddelerin, "Sınıf Yönetimi Algısı" olarak isimlendirilen alt ölçeğinde toplandığı gözlemlenmiştir. Sınıf yönetimi boyutları Martin ve Sass (2010) çalışması teorik yapısı temel alındığı için, sınıf yönetimine yönelik algılar başlangıçta davranışsal ve öğretimsel yönetim olarak iki boyutlu düşünülmesine rağmen, bu çalışmada tek faktörde toplandığı bulunmuştur.

\section{SONUÇ, TARTIŞMA VE ÖNERILER}

Bu çalışmada, sınıf yönetimini yapılandırmacı bakış açısıyla ele alan ve farklı branşlardaki öğretmen adaylarının yapılandırmacı bir sınıf yönetimi algısına ne kadar sahip olduklarını belirlemeye yönelik, sınıf yönetimini hem öğretimsel hem de davranışsal yönetimi boyutlarda temel alan bir sınıf yönetim algısı ölçeği geliştirilmesi hedeflenmiştir. Ancak bu ölçekte davranışsal ve öğretimsel boyutlarının varlığından söz edilememektedir. Genel olarak öğretmen adaylarının, sınıf yönetim algılarından bahsedilebilmektedir. Araştırmacının sınırlı erişimi nedeniyle, az örnekleme ulaşması ile ancak açımlayıcı faktör analizi ile geçerlik ve güvenirlik analizleri yapılabilmiştir. Bu nedenle bu ölçek çalışması, faktör yapısını ortaya çıkarmak için yapılan bir ön çalışma olarak belirtilebilir. Ölçek geliştirilirken, farklı branşlardaki öğretmen adayları ile çalışılması, sınıf yönetimine yeni bakış açısının getirdiği yaklaşımların temel alınması ile yeni bir çalışma olması nedeniyle önem gösterdiği belirtilebilir.

Bu çalışmada, sınıf yönetiminin teorik alt yapısı, Martin ve Sass (2010) çalışmasındaki sınıf yönetimi boyutları temel alınarak oluşturulmuştur. Ancak çalışmadaki maddeler olduğu gibi alınmamış, ilgili literatürden, uzman görüşlerinden ve öğretmen adaylarının açık uçlu sorulara verdikleri yanıtların teoriye uyanlara seçilmesi ile yeni bir ölçek geliştirmek istenmiştir. Bunun nedeni, diğer çalışmalardan farklı olarak veli ve okul işbirliği boyutlarının ve yapılandırmacı paradigmanın çalışmaya dahil edilmek istenmesidir. Ancak temel alınan teoriye göre öğretmenlerin sınıf yönetimine ilişkin algıları, öğretimsel yönetim ve davranışsal yönetim alt boyutları ile şekillenmektedir. Bu iki boyut birbiriyle ilişkilidir. Öğretimsel yönetim, öğretmenin sınıf içinde eğitimi düzenlemek için uyguladıklarına yönelik algıları; davranışsal yönetim ise sınıf içerisinde ortaya çıkabilecek davranışların yönetilmesine dair algılara yöneliktir. Bu kapsamda öğretmenin önleyici disiplin yaklaşım müdahaleleri, gücünü tek öğretmen otoritesinden almayan, öğretmenin kontrol yaklaşımını ifade eden etkileşimci yaklaşımı, öğretmenin etkili davranış yönetimi için sahip olması gereken özelliklere yönelik algıları, davranışsal yönetiminin belirleyicileri 
olduğu

düşünülmektedir.

Ölçekteki

maddeler

$(6,15,16,17,18,19,20,21,22,23,24,25,26,27,28,32,33,34,35,37,38,41,44,45,47,48,49$ ve 50.$) ;$ davranış yönetimi ilgili kuramdan yararlanılarak ve veli ile okul işbirliği ve yapılandırmacılık paradigması ile yapılandırılarak yeni bir ölçek oluşturulmaya çalışılmıştır. Diğer maddelerin ise, öğretimsel yönetim ile ilişkili olarak oluşturulmak istendiği belirtilebilir. Ancak yapılan analizler sonrasında bu boyutların tek, genel bir boyut (sınıf yönetimi algısı) altında toplandığı ve başta belirtilen iki boyutun bu araştırmada çalışmadığı belirtilebilir.

Ölçek geliştirilirken, literatür taraması yapılmış, teorik çerçevesi çizilmiş ve öğretmen adayları, uzman görüşlerine başvurularak madde havuzu oluşturulmuştur. Öğretmen adaylarının sınıf yönetimi algısını ölçmek üzere geliştirilen ön deneme çalışması yapılan ölçekte 57 madde bulunmaktaydı. Ölçeğin kapsam geçerliği ölçekte yer alacak ifadeler ve boyutlar için eğitim bilimi uzmanı olan dört akademisyenin görüşü alınmıştır. Dilin incelenmesi için iki akademisyenin ve ölçme-değerlendirme için bir akademisyenin görüşü alınmıştır. Geçerlik ve güvenirlik testinden sonra, 7 madde çıkartılarak madde sayısı 50'ye düşmüştür. Ölçeğin yapısı için geçerlik çalışması olarak temel bileşenler analizi ile açımlayıcı faktör analizi yapılmıştır. Ölçeğin Cronbach's alfa güvenirlik katsayısının .973 olması, kabul edilebilir düzeyin üstünde olduğunu ortaya çıkarmaktadır. Açımlayıcı faktör analizi ile toplam varyansın \%51,006'sının açıklandığı bulunmuştur. Özdeğeri 1,00'ın üzerinde tek faktörlü yapıya ulaşıımıştır. Bulgular sınıf yönetimi ölçeğinin tek faktör yapısına sahip olduğunu olduğunu göstermiştir. Bu tek faktör yapısı, "Sınıf yönetim Algısı" olarak isimlendirilmiştir.

Literatür incelendiğinde; Akın, Erguvan, Sarıçam, Yalnız, Güler ve Özdemir (2013) tarafından Martin ve Sass (2010) çalışmasının farklı branşlarda çalışan öğretmenlerde uyarlama çalışmasında da iki boyut çalışmıştır. Şahin-Sak, Tantekin-Erden ve Pollard-Durodola (2018, s.102) okul öncesi öğretmenleri ile yaptıkları çalışmada, Martin ve Sass'ın (2010) teorik yapısı temel alınmış ve sınıf yönetim boyutları dört boyutlu olarak belirlenmiştir. Ancak bu çalışmada literatürdeki sınıf yönetim algısına yönelik çalışmalardan farklı olarak faktörlerin tek boyutta toplandığı bulunmuştur. Bunun nedeni olarak; Martin ve Sass'ın (2010) çalışması teoride yararlanılmasına rağmen, maddelerin diğer kaynaklardan ve uzman görüşlerinden yararlanılarak seçilmesinin, örneklemin sayısı ve yapı özelliklerinin etkisi olabileceği düşünülebilir. Bu bağlamda ileride yapılacak çalışmaların daha büyük örneklemlerle gerçekleştirilmesi ve çalışma grubu olarak farklı okullarda veya branşlarda öğrenim gören öğretmen adaylarının seçilmesi ile bu ölçme aracının faktör yapısının tekrar incelenmesi, daha güçlü bir ölçme aracı geliştirilmesi için önemli görülmektedir.

Tek boyuttan oluşan, 5'li Likert tipindeki Öğretmen Adaylarında Sınıf Yönetimi Algısı ölçeğinin geçerlik ve güvenirliğinin yüksek olması, farklı branşlarda öğrenim gören öğretmen adaylarında, geliştirilerek kullanılabilir olduğunu göstermektedir. Bu ölçekteki maddeler farklı sayıda ve farklı örneklemlerle tekrar test edilebilir. Açımlayıcı faktör analizi ile belirlenen faktör yapısın verilerle nası uyum verdiğinin anlaşılması için doğrulayıcı faktör analizinin yapılması gerekmektedir. Ayrıca sınıf yönetim algısı, önceden ilişkili olduğu bilinen öğretmenlerin sınıf yönetimine ilişkin yetkinlik algısı, yeterlilik algısı gibi diğer değişkenlerce ilişkisi incelenebilir. Öğretmen adaylarının sınıf yönetimine ilişkin algıları; branşı, cinsiyeti, yaşı değişkenlerine göre karşılaştııılarak gruplar arası farklar değerlendirilebilir. Öğretmen adaylarının sınıf yönetim algıları belirlenerek, sınıf yönetimine ilişkin verilen eğitim içerikleri düzenlenebilir ve bu yöndeki çalışmalar, öğretmen yetiştirme politikaları için katkı sağlayabilir.

\section{KAYNAKLAR}

Ağaoğlu, E. (2004). Sınıf yönetimiyle ilgili genel olgular. Z. Kaya (Ed.). Sınıf yönetimi (s. 1-18). Ankara: Pegem A Yayıncılık.

Akar, H., Tantekin Erden, F., Tor, D. ve Şahin, İ. T. (2010). Öğretmenlerin sınıf yönetimi yaklaşımları ve deneyimlerinin incelenmesi. Ilköğretim Online, 9(2), 792-806. 
Akın, A., Erguvan, F. M., Sarıçam, H., Yalnız, A., Güler, H. \& Özdemir, E. (2013). Öğretimsel ve davranışsal yönetim ölçeği Türkçe formunun yapı geçerliği. International Conference on Innovation and Challenges in Education (CICE), 26-28 Nisan, Kütahya, Türkiye.

https://www.researchgate.net/publication/271853658_Ogretimsel_ve_Davranissal_Yonetim_Olcegi_T urkce Formu'nun yapi gecerligi.

Akın, S., Yıldıım, A., \& Goodwin, A. L. (2016). Classroom management through the eyes of elementary teachers in Turkey: A phenomenological study. Educational Sciences: Theory \& Practice, 16, 771-797.

Aktan, S. \& Sezer, F. (2018). Sınıf yönetimi stilleri ölçeği' nin psikometrik özelliklerinin incelenmesi. Kastamonu Education Journal, 26(2), 439-449. Doi:10.24106/kefdergi.389803.

Başar, Hüseyin.(1999) Sınıf Yönetimi. İstanbul: M.E.B. Yayınları.

Bosworth, B. (1997). What is your classroom management profile? Teacher talk-a publication for secondary education teachers, 1(2). http://protectiveschools.org/drugstats/tt/v1i2/what.html.

Büyüköztürk, Ş. (2016). Sosyal bilimler için veri analizi el kitabı (22. Baskı). Ankara: Pegem Akademi.

Cattell, R.B. (1978). The scientific use of factor analysis in behavioral and life sciences. New York: Plenum.

Chow, J. C., \& Gilmour, A. F. (2015). Designing and implementing group contingencies in the classroom. TEACHING Exceptional Children, 48, 137-143. Doi: 10.1177/0040059915618197.

Çandar, H. ve Şahin, A. E. (2013). Yapılandırmacı yaklaşımın sınıf yönetimine etkilerine ilişkin öğretmen görüşleri. Hacettepe Üniversitesi Eğitim Fakültesi Dergisi, 44, 109-119.

Demirtaş, H. (2005). Sınıf yönetiminin temelleri. H. Kıran (Ed.), Etkili Sınıf Yönetimi içinde (s. 1-32). Ankara: Anı Yayıncılık.

Elçiçek, Z., Kinay, İ. ve Oral, B. (2015). Öğretmen adaylarının sınıf yönetimi yeterlik ölçeğinin geliştirilmesi: geçerlik ve güvenirlik çalışması. Bartın Üniversitesi Eğitim Fakültesi Dergisi, 4(1), 51-63.

Ercoşkun, M. H. ve Ada, Ş. (2013). Etkili sınıf yönetimi oluşturmada sınıf öğretmenlerinin yeni rollerinin nitel açıdan incelenmesi. Adnan Menderes Üniversitesi Eğitim Fakültesi Eğitim Bilimleri Dergisi, 4(1), 60-79.

Gage, N. A., Scott, T., Hirn, R. \& MacSuga-Gage, A. S. (2018). The relationship between teachers' implementation of classroom management practices and student behavior in elementary school. Behavioral Disorders, 43(2), 302-315. Doi:10.1177/0198742917714809 journals.sagepub.com/home/bhd.

Glickman, C. D. \& Tamashiro, R. T. (1980). Clarifying teachers' beliefs about discipline. Educational Leadership, 37, 459-464.

Gorsuch, R. L. (1983). Factor analysis. Hillsdale, NJ: Erlbaum.

Gökçe, E. (2015). The development of a scale to determine general competency for primary school teachers in Turkey: A validity and reliability study. The Anthropologist, 20(1-2), 360-368. Doi: 10.1080/09720073.2015.11891740.

Kalin, J., Peklaj, C., Pecjak, S., Levpušcek, M. P. \& Zuljan, M. V. (2017). Elementary and secondary school students' perceptions of teachers' classroom management competencies. Center for Educational Policy Studies Journal, 7(4), 37-62.

Martin, N. K. \& Baldwin, B. (1993). An examination of the construct validity of the inventory of classroom management style. Paper presented at the annual conference of the Mid-South Educational Research Association, New Orleans, LA. http://www.eric.ed.gov/contentdelivery/servlet/ERICServlet?accno=ED365723.

Martin, N. K. \& Sass D. A. (2010). Construct validation of the behavior and instructional management scale. Teaching and Teacher Education, 26, 1124-1135.

Martin, N. K., Yin, Z. \& Baldwin, B. (1997). Beliefs regarding classroom management style: Differences between male \& female, urban \& rural secondary level teachers. Paper presented at the annual conference of the American Educational Research Association, Chicago, IL. https://eric.ed.gov/?id=ED408136.

Martin, N. K., Yin, Z. \& Baldwin, B. (1998). Classroom management training, class size and graduate study: Do these variables impact teachers' beliefs regarding classroom management style? Paper presented at the Annual Conference of the American Educational Research Association, San Diego, CA. https://files.eric.ed.gov/fulltext/ED420671.pdf

Martin, N. K., Yin, Z. \& Mayall, H. (2006). Classroom management training, teaching experience and gender: do these variables impact teachers' attitudes and believes toward classroom management style? Paper presented at the annual conference of the Soutwest Educational Research Association, Austin, TX. http://files.eric.ed.gov/fulltext/ED494050.pdf.

Özcan, G. ve Gülözer, K. (2017). Sınıf yönetimi ölçeğinin geliştirilmesi. Kastamonu Eğitim Dergisi, 25(3), $1133-1146$. 
Özenç İra, G. ve Çelebi Öncü, E. (2017). Temel eğitimde görev yapan öğretmenlerin davranışsal-öğretimsel sınıf yönetim algılarının incelenmesi. International Journal of New Trends in Arts, Sports \&Science Education (IJTASE), 6(3).

Postholm, M. B. (2013). Classroom management: what does research tell us?. European Educational Research Journal (EERJ), 12(3), 389-402. http://dx.doi.org/10.2304/eerj.2013.12.3.389.

Sass, D. A., Lopes J., Oliveira C. \& Martin N. K. (2016). An evaluation of the Behavior and Instructional Management Scale's psychometric properties using Portuguese teachers', Teaching and Teacher Education, 55, 279-290.

Savran, A. \& Çakıroğlu, J. (2003). Differences between elementary and secondary preservice science teachers' perceived efficacy beliefs and their classroom management beliefs. The Turkish Online Journal of Educational Technology, 2(4), 15-20.

Savran, A. \& Çakıroğlu, J. (2004). Preservice science teachers' orientations to classroom management. Hacettepe University Journal of Education Faculty, 26, 124-130.

Stronge, J. H., Ward, T. H. \& Grant, L.W. (2011). What makes good teachers good? A cross-case analysis of the connection between teacher effectiveness and student achievement. Journal of Teacher Education, 62(4), 339-355. http://dx.doi.org/10.1177/0022487111404241.

Şahin, A . (2015). Comprehending elementary school teachers' classroom management approaches. International Journal Of Progressive Education, 11(3), 131-139. Retrieved from http://dergipark.gov.tr/ijpe/issue/26330/277429.

Şahin, ì. ve Altunay, U. (2011). İlköğretim okulu öğretmenlerinin sınıf yönetimi davranışları. ilköğretim Online, 10(3), 905-918.

Şahin-Sak, I. T., Tantekin-Erden F. \& Pollard-Durodola, S. (2018). Turkish preschool teachers' beliefs and practices related to two dimensions of developmentally appropriate classroom management Education 3-13, 46(1), 102-116, Doi:10.1080/03004279.2016.1194447.

Tabachnick, B. G. \& Fidell, L. S. (2007). Using multivariate statistics. Boston: Allyn and Bacon.

Tanhan, F. ve Şentürk, E. (2011). Sınıf içi istenmeyen öğrenci davranışlarına yönelik öğretmen tutumları ölçeğinin geliştirilmesi. Türk Psikolojik Danışmanlık ve Rehberlik Dergisi, 4(35), 44-53.

Temli-Durmuş, Y. (2016). Development of Classroom Management Scale for science teachers. Universal Journal of Educational Research, 4(9), 1950-1957. Doi:10.13189/ujer.2016.040904.

Toprakçı, E. (2008). Sınıfa dayalı yönetim. Ankara: Pegem Akademi.

Toprakçı, E. (2012). Rethinking Classroom Management: A new perspective, a new horizon. e-International Journal of Educational Research, 3(3), 84-110.

Yılmaz, Z. N. ve Şahin, A. E. (2016). An analysis of elementary schools teachers' classroom control levels. Universal Journal of Educational Research, 4, 1387 - 1394. Doi: 10.13189/ujer.2016.040616. 


\section{Developing a Classroom Management Perceptions Scale for Teacher Candidates: Validity and Reliability Study}

\author{
Res. Assist. Gözde Özenç Ira \\ Hacettepe University-Turkey \\ gozdeozenc@gmail.com
}

\author{
Assoc. Prof. Dr. Nejat ira \\ Çanakkale Onsekiz Mart University-Turkey \\ nejat.ira@gmail.com
}

\begin{abstract}
Classroom management is a systematic activity performed in the classrooms. Teachers' perceptions of classroom management also affect teachers' in-class practices. Because of this, it is important to develop a current instrument that measures teachers' perceptions of classroom management. The aim of this study is to develop classroom management perceptions scale for teacher candidates and this study was based on Martin ve Sass' (2010) classroom management theoretical frame and constructivist paradigm. This scale development study was considered as a preliminary study. In the preparation phase of the scale was used the teacher candidates answers to questions, the literature related to classroom management in addition to domain expert's feedbacks. In the academic year 2017-2018, the working group comprised a total of 112 students which are in Çanakkale Onsekiz Mart University. 'The Classroom Management Perceptions of The Teacher Candidates Scale' consisted of 50 items. The Cronbach's alpha reliability of this scale was determined by 0,973. The scale is compatible with a single factor model. 'The Classroom Management Perceptions of The Teacher Candidates Scale' consisted of 50 items. The scale can be said as reliable and valid. It is appropriate for determining for the teacher candidate's regarding classroom practices perceptions and can be used if improving with different teacher candidate's branch. The items of this scale can be retested with different samples.
\end{abstract}

Keywords: Classroom management, teacher candidates, developing scale

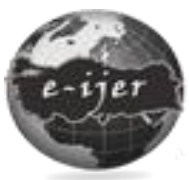

E-International Journal of Educational

Research,

Vol: 9, No: 3, 2018, pp.104-118

DOI: 10.19160/ijer.488221

\section{Suggested Citation:}

Özenç İra, G. \&. İra, N. (2018). Developing a Classroom Management Perceptions Scale for Teacher Candidates: Validity and Reliability Study, E-International Journal of Educational Research, Vol: 9, No: 3, 2018, pp. 104-118, DOI: 10.19160/ijer.488221 


\section{EXTENDED ABSTRACT}

Purpose: Classroom management can be express to systematic activities performed in the classrooms. It covers to reach the aims of the education was determined plans, practice and evaluation functions with the appropriate principles, theories, methods and models (Ağaoğlu, 2004). For this reason, classroom management is the crucial factor of the education and then can be affected by many variables such as teachers classroom management perceptions (Şahin and Altunay, 2011). It may be said that the roles of education and teachers in the classroom are advancing, teachers perceptions of the classroom management differ (Ercoşkun and Ada, 2013). Nowadays, teachers not knowing everything, but motivate the students for gaining knowledge. In order to carry out these roles of the teachers, they have to use classroom management effectively (Demirtaş, 2005). Teachers' perceptions of classroom management also affect teachers' in-class practices. According to the Martin and Sass' basic theory (2010), perceptions of teachers about classroom management are composed of instructional management and behavioral management sub-dimensions. These two dimensions are interrelated. Instructional management; are perceptions that the teacher has practiced to organize education within the classroom. Behavioral management is perceived as the management of behaviors that may emerge within the classroom.

Previous studies show that classroom management consists of three broader and multiple dimensions: personality, instruction, and discipline (Martin and Baldwin, 1993). Similarly, other studies determined three-factor: instructional management, people management and behavioral management (Martin, Yin and Baldwin, 1997; Martin, Yin and Mayall, 2006). Martin and Sass (2010) stated that these dimensions consist of instructional and behavioral management. The aim of this study is to develop classroom management perceptions scale for teacher candidates and this study was based upon Martin ve Sass (2010) classroom management theoretical frame.

Methodology: In the preparation phase of the scale was used the teacher candidates answers to questions, the literature related to classroom management in addition to domain expert's opinions. In the academic year 2017-2018, the working group comprised a total of 112 students which are in Çanakkale Onsekiz Mart University. 56,25\% of participants are women and the rest of man. 53,57\% of participants from the Psychological Counseling and Guidance, 10,71\% from German Teaching, 16,07\% of Japanese Teaching, rest from Physical Education Teaching. Teacher candidates are chosen by simple random sampling method.

To develop pre-scale was examined related to articles, books, thesis. In addition to developing Martin and Sass (2010) theoretical frame of the classroom management, teacher candidates answered the open-ended five questions. At the end of this process, 51-item pool, which is considered to represent classroom management perception, has been developed. With the need of the content validity, the opinions of the domain experts in educational sciences have taken. As a result of this, some items are reorganized and new items are added. At the end of this process, the 57-item pool was developed.

In the analyzing of data; standard deviation, percent, factor analysis and reliability analysis were used. In order to ensure construct validity and to develop subdimensions, with the principal factor analysis, exploratory factor analysis was used.

Results: In this study, Kaiser Mayer Olkin (KMO) coefficient is .924. This is bigger than .60 and suitable for factor analysis. At the end of Barlett Test found that chi-square coefficient is 7281,388; the degree of freedom: 1596, p:000. For structure validity, basic component analyses were used and found that developed scale explains 51,006 of total variance and have a single factor structure which eigenvalue bigger than 1.00. It was found that the item difficulty indices were between .840 and .326. At the end of the discrimination of items, 7 items was dismissed. Because their total correlation was less than 0.30. 'The Classroom Management Perceptions of The Teacher Candidates Scale' consisted of 50 items. The Cronbach's alpha reliability of this scale was determined as .973. 
Discussion and Conclusions: 'The Classroom Management Perceptions of The Teacher Candidates Scale' consisted of 50 items. The Cronbach's alpha reliability of this scale was determined as .973. The results of the confirmatory factor analysis show that the scale has a single factor structure. The scale is reliable and valid. It is appropriate for determining for the teacher candidate's regarding classroom practices perceptions. This scale development study was considered as a preliminary study. The factor structure in this study can be reorganized with larger and different samples. Confirmatory factor analysis is needed to understand how the factor structure determined in this study matches with the given structure. In addition, the relationship between classroom management perceptions, other perceived competencies such as competence perception of classroom management, teacher's self efficacy can be examined. Perceptions of teacher candidates about classroom management can be compared with the branch, gender, and age of prospective teachers. Determining the classroom management perceptions of the teacher candidates may contribute to the reorganization of the educational contents related to classroom management. 